\title{
Correction to: Developing japonica rice introgression lines with multiple resistance genes for brown planthopper, bacterial blight, rice blast, and rice stripe virus using molecular breeding
}

\author{
Suk-Man Kim² $\cdot$ Russell Reinke ${ }^{1,2}$ (1) $\cdot$ Bo-Kyeong Kim ${ }^{3}$
}

Published online: 24 July 2018

๑) Springer-Verlag GmbH Germany, part of Springer Nature 2018

\section{Correction to: Molecular Genetics and Genomics https://doi.org/10.1007/s00438-018-1470-1}

In the original publication, the author sequence is incorrect. The correct author sequence is Dr. Suk-Man Kim as first author, followed by Russell Reinke and Bo-Kyeong Kim.

The original article can be found online at https://doi.org/10.1007/ s00438-018-1470.

Russell Reinke

r.reinke@irri.org

1 Strategic Innovation Platform, International Rice Research Institute, Los Baños, Philippines

2 C/o IRRI-Korea Office, National Institute of Crop Science, Rural Development Administration, Iseo-myeon, Wanju-gun, Republic of Korea

3 National Institute of Crop Science, Rural Development Administration, Iseo-myeon, Wanju-gun, Republic of Korea 